\title{
Review Article \\ Regulation and Roles of Urocortins in the Vascular System
}

\author{
Kazunori Kageyama, Ken Teui, Naoki Tamasawa, and Toshihiro Suda \\ Department of Endocrinology and Metabolism, Hirosaki University Graduate School of Medicine, 5 Zaifu-cho, \\ Hirosaki, Aomori 036-8562, Japan \\ Correspondence should be addressed to Kazunori Kageyama, kkageyama@hkg.odn.ne.jp
}

Received 8 February 2012; Revised 6 March 2012; Accepted 6 March 2012

Academic Editor: Keiichi Ikeda

Copyright ( 12012 Kazunori Kageyama et al. This is an open access article distributed under the Creative Commons Attribution License, which permits unrestricted use, distribution, and reproduction in any medium, provided the original work is properly cited.

\begin{abstract}
Urocortins (Ucns) are members of the corticotropin-releasing factor (CRF) family of peptides. Ucns would have potent effects on the cardiovascular system via the CRF receptor type $2\left(\mathrm{CRF}_{2}\right.$ receptor). Regulation and roles of each $\mathrm{Ucn}$ have been determined in the vascular system. Ucns have more potent vasodilatory effects than CRF. Human umbilical vein endothelial cells (HUVECs) express Ucns1-3 mRNAs, and the receptor, $\mathrm{CRF}_{2 \mathrm{a}}$ receptor mRNA. Ucns1-3 mRNA levels are differentially regulated in HUVECs. Differential regulation of Ucns may suggest differential roles of those in HUVECs. Ucn 1 and Ucn 2 have strong effects on interleukin (IL)-6 gene expression and secretion in rat aortic smooth muscle A7r5 cells. The increase that we observed in IL-6 levels following Ucn treatment of A7r5 cells suggests that smooth muscle cells may be a source of IL-6 secretion under physiological stress conditions. Ucns are important and unique modulators of vascular smooth muscle cells and act directly or indirectly as autocrine and paracrine factors in the vascular system.
\end{abstract}

\section{Introduction}

Corticotropin-releasing factor (CRF) plays a central role in controlling the hypothalamic-pituitary-adrenal (HPA) axis during stress [1]. Urocortins (Ucns) are also members of the CRF family of peptides. Three Ucns have been found in mammals. Ucn1 is a 40-amino-acid peptide cloned from the Edinger-Westphal nucleus [2], and Ucn2 and Ucn3 are identified in the human genome data base and in mouse genomic DNA, respectively [3-5]. Ucn1 and/or Ucn2 is expressed in the heart, vascular, and peripheral blood cells [3-8], while the expression of Ucn3 also has been reported in the human cardiovascular system [9]. The Ucns have been demonstrated to play important modulatory roles in various tissues including the brain, immune system, cardiovascular system and gastrointestinal system, and may be important in the various stages of atherosclerosis development [10].

The actions of the CRF family peptides are mediated by at least two distinct $\mathrm{G}$ protein-coupled receptors, namely, the CRF receptor type $1\left(\mathrm{CRF}_{1}\right.$ receptor) [11-13] and CRF receptor type $2\left(\mathrm{CRF}_{2}\right.$ receptor) [14-16]. These two receptors share $69 \%$ amino acid homology [17], but have different tissue distributions and pharmacological properties with respect to ligands [10]. $\mathrm{CRF}_{1}$ receptor is the major subtype responsible for regulating synthesis and secretion of adrenocorticotropic hormone (ACTH) in the pituitary corticotrophs [18], whereas $\mathrm{CRF}_{2}$ receptor with splice variants is found in the brain and in peripheral sites including the cardiac myocytes and vascular smooth muscles $[19,20]$. CRF has higher affinity for the $\mathrm{CRF}_{1}$ receptor than for the $\mathrm{CRF}_{2}$ receptor (Figure 1). Ucn1 binds to both the $\mathrm{CRF}_{1}$ and $\mathrm{CRF}_{2}$ receptors, while $U \mathrm{cn} 2$ and $U \mathrm{cn} 3$ are highly selective for the $\mathrm{CRF}_{2}$ receptor, with little affinity for the $\mathrm{CRF}_{1}$ receptor (Figure 1) $[2,4,5]$.

$\mathrm{CRF}_{2 \mathrm{~b}}$ receptor is a member of the Class $\mathrm{B}$ heptahelical $\mathrm{G}$ protein-coupled receptors. This receptor is positively coupled to adenylate cyclase and is bound preferentially by the CRF-related peptides, Ucns. In the rodent, $\mathrm{CRF}_{2 \mathrm{~b}}$ receptor messenger RNA (mRNA) is expressed in the cardiovascular system, where its levels can be modulated by Ucns [24]. Ribonuclease protection assays show that $\mathrm{A} 7 \mathrm{r} 5$ cells express the $\mathrm{CRF}_{2 \mathrm{~b}}$ receptor subtype, which have two isoforms differing in one codon at the junction of exons 3 and 4 [25]. Ucn induces accumulation of intracellular cAMP via $\mathrm{CRF}_{2 b}$ receptor. Ucn induces intracellular cAMP to downregulate $\mathrm{CRF}_{2 \mathrm{~b}}$ receptor mRNA expression in A7r5 cells [25]. $\mathrm{CRF}_{2}$ 


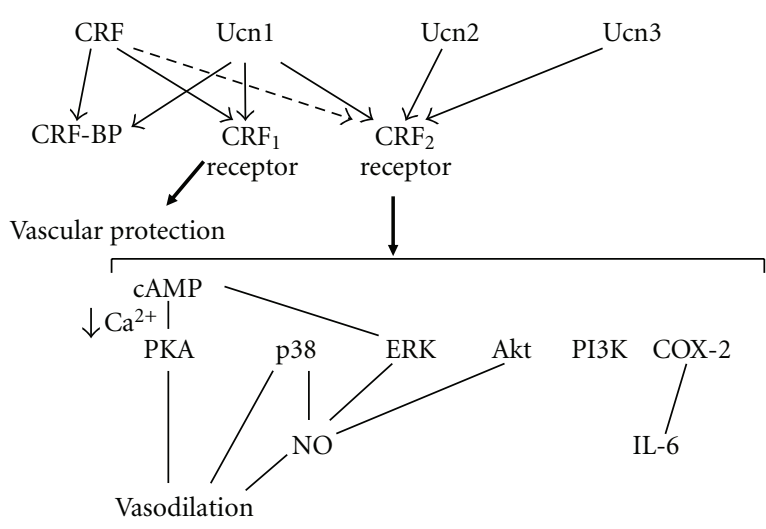

Figure 1: Proposed signaling mechanisms of Ucns and CRF receptors in the vascular system. CRF-BP, CRF-binding protein.

ligands or dexamethasone reduces $\mathrm{CRF}_{2 \mathrm{~b}}$ receptor mRNA levels [24]. In addition, a variety of cytokines also reduce $\mathrm{CRF}_{2}$ mRNA expression [24]. The multifactorial regulation of $\mathrm{CRF}_{2}$ mRNA expression in the cardiovascular system may serve to limit the inotropic and chronotropic effects of Ucns during prolonged physical or immune challenge.

\section{Expression and Regulation of Ucns in the Vascular System}

Human umbilical vein endothelial cells (HUVECs) express Ucns 1-3 mRNAs, and the receptor, $\mathrm{CRF}_{2 \mathrm{a}}$ receptor mRNA, suggesting an endogenous role of each $U c n$ via the $C_{R F}$ a receptor in HUVECs (Figure 2) [21]. Endogenous Ucn in the system might act in an autocrine or paracrine manner [26]. Endothelial Ucn1, upregulated by inflammatory cytokines and pitavastatin, suppresses reactive oxygen species production in endothelial cells [7]. The data suggest that endothelial Ucn1 has potent antioxidative properties [7]. Lipopolysaccharide (LPS) decreases Ucn 1 mRNA levels, while it increases Ucn 2 and Ucn3 mRNA levels in HUVECs [21]. LPS would regulate Ucns gene expression levels directly through Tolllike receptors. After immune stimulation, tumor necrosis factor (TNF)- $\alpha$, interleukin (IL)-1, and IL-6, are elevated in the systemic circulation. These cytokines also increase the activity of the HPA axis, resulting in the release of additional ACTH and corticosterone [27, 28]. Among them, IL- $1 \beta$ is a pleiotropic cytokine with a variety of biological activities. IL- $1 \beta$ decreases Ucn 1 and Ucn 2 mRNA levels, while it increases Ucn 3 mRNA levels in HUVECs [21]. These data are consistent with changes in mRNA levels of Ucn 1 and Ucn3 following LPS. Therefore, IL-1 and LPS may contribute cooperatively to regulate the levels of $U \mathrm{cn} 1$ and $U \mathrm{cn} 3$ mRNA in the vascular cells.

Forskolin stimulates adenylate cyclase and then intracellular cAMP in HUVECs. Norepinephrine, prostacyclin, and adiponectin may be candidates for natural ligands to activate cAMP pathway in HUVECs [29-31]. These peptides or hormones can regulate Ucns via the cAMP production in HUVECs, although this association remains speculate. Ucns also regulate own or other Ucns in an autocrine or paracrine manner via the cAMP pathway. In fact, forskolin increases Ucn 1 mRNA levels, while it decreases Ucn2 and Ucn3 mRNA levels in HUVECs. In both the mouse and human Ucn promoters, there is a consensus cAMP response element (CRE) site, which has been shown to mediate the regulation of Ucn expression by cAMP [32]. The CRE binding protein via the protein kinase A (PKA) pathway may be involved in this pathway. Ucn 2 and $U \mathrm{cn} 3 \mathrm{mRNA}$ levels are decreased presumably due to increase in mRNA degradation or decrease in the mRNA synthesis. Differential regulation of Ucns1-3 mRNA may suggest differential roles of those in HUVECs.

\section{Roles and Action of Urocortins in the Vascular System}

Recent studies have shown the potent effects of Ucns on the cardiovascular system. Taken together with the expression of Ucns and the receptor, endogenous Ucns have a physiological role in the cardiovascular system. Vasodilatory effects of Ucns have been demonstrated in rat tail and basilar arteries [33, 34]. Ucn 1 produces vasodilation via the adenylate cyclase and PKA pathway [34]. Furthermore, Ucn1 and Ucn2 have more potent vasodilatory and cardiac inotropic effects than CRF, with a greater potential to increase coronary blood flow and reduce overall blood pressure $[34,35]$. In our previous study, Ucns1-3 were more potent vasodilators than CRF in a rat thoracic aorta model (Figure 3) [22]. Ucns contribute to vasodilation via p38 mitogen-activated protein (MAP) kinase and PKA pathways (Figure 1). In vascular smooth muscle cells, stimulation of $\mathrm{CRF}_{2}$ receptors results in increased cAMP accumulation via activation of adenylate cyclase [25]. It is at least possible that increased cAMP levels contribute to vasorelaxant responses, although the role of cGMP remains unclear. Ucns exert their vasorelaxant effects via $G \alpha$ s-cAMP-PKA signaling, leading to downregulation of the phospholipase $C \beta$-inositol 1, 4, 5-triphosphatase$\mathrm{Ca}^{2+}$ signaling pathway (Figure 1) [36]. The Ucns-induced endothelium-dependent relaxation of rat coronary arteries would be also attributable to endothelial nitric oxide (NO) (Figure 1). Ucn2 induces NO production through cAMPdependent and $\mathrm{Ca}^{2+}$-related phosphorylation of extracellular signal-related kinases (ERKs), Akt, and p38 pathways in aortic endothelial cells (Figure 1) [37]. In addition, we reported a first case of multiple endocrine neoplasia type II without hypertension, accompanied by thyroid medullary carcinoma and pheochromocytomas expressing CRF, Ucn1, and Ucn3 [38]. This case highlights that CRF and Ucn1 secreted from the adrenal pheochromocytomas and thyroid tumor might induce vasodilation.

Ucn2 significantly reduces blood pressure in hypertensive rats without affecting heart rate [39]. Long-term Ucn2 treatment in hypertensive rats induces sustained blood pressure reduction and diminishes the development of hypertensioninduced left ventricular hypertrophy and the deterioration of left ventricular contractile function [39]. $\mathrm{CRF}_{2}$ receptor expression levels are preserved, despite chronic stimulation by $U \mathrm{cn} 2$. Ucn also may play a role in vascular remodeling 


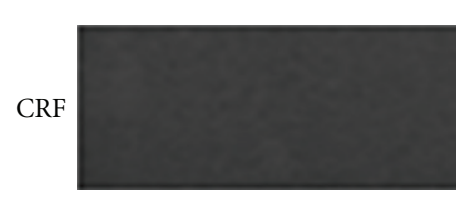
678 bp
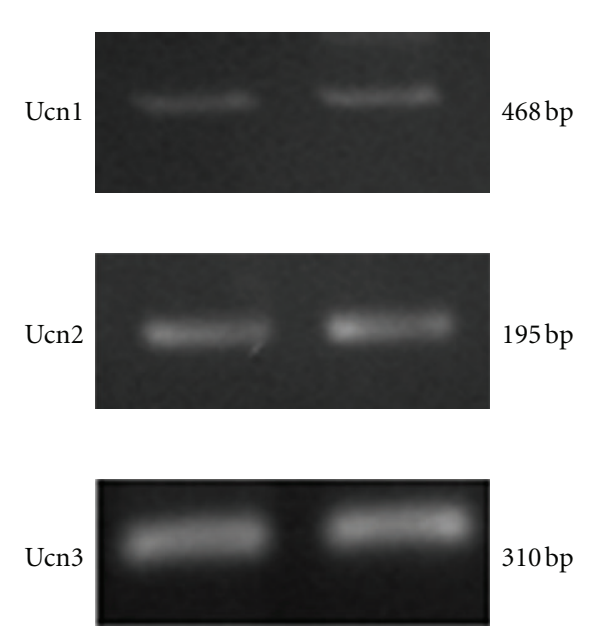
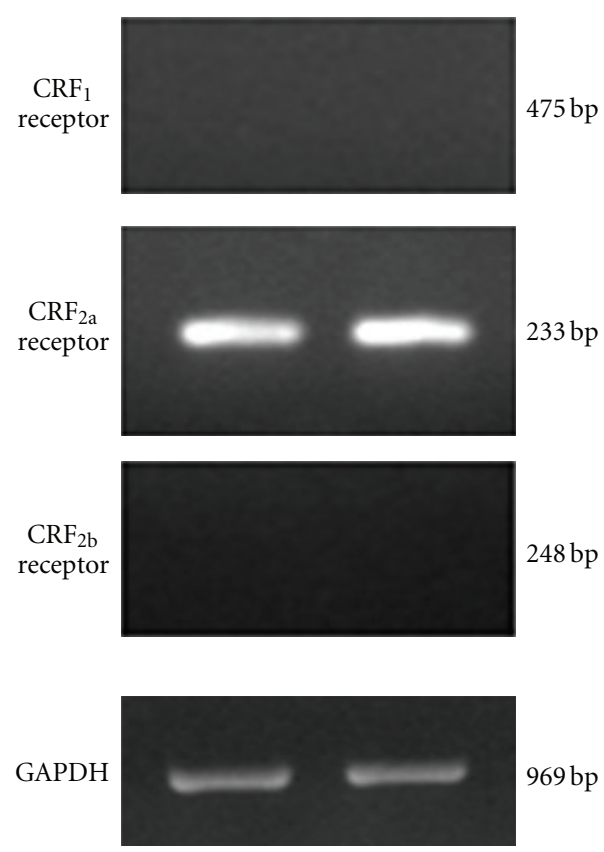

FIGURE 2: Expression of Ucns and CRF receptors mRNA in HUVECs. A representative image of RT-PCR for Ucns and CRF receptors mRNA in HUVECs. Reproduction from [21] with permission of the publisher. Copyright 2009, Elsevier.

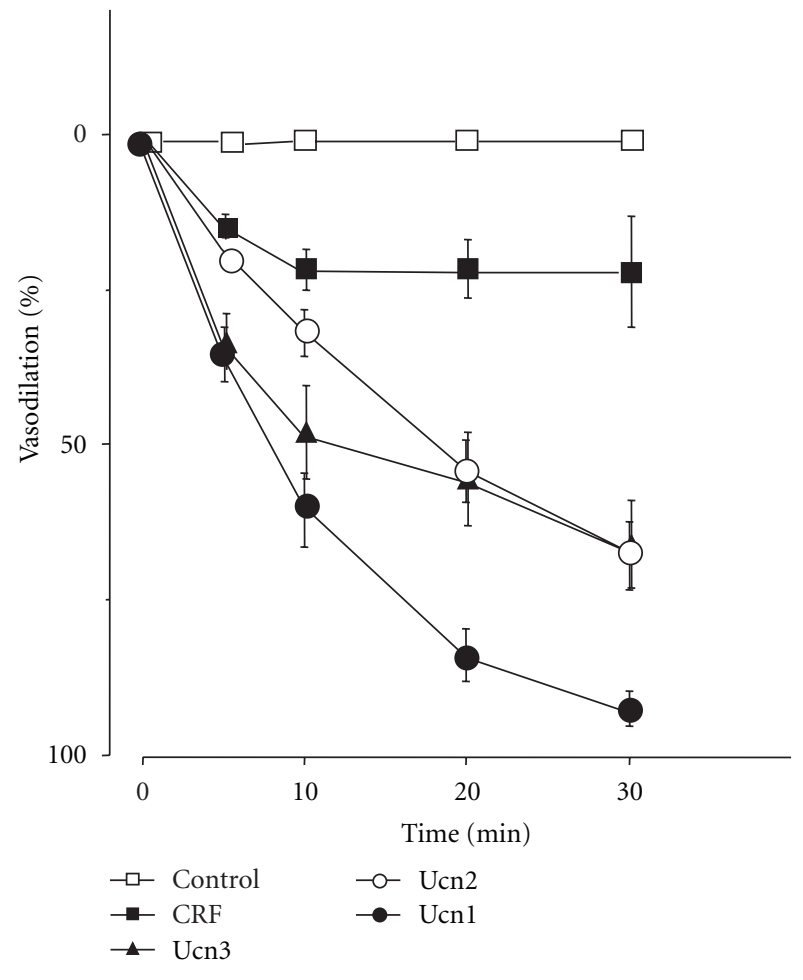

FIGURE 3: Effects of CRF and Ucns on vasodilation. Rat aortae were incubated with medium alone (control) or with medium containing $1 \mu \mathrm{M}$ of CRF, Ucn $1, \operatorname{Ucn} 2$, or $\operatorname{Ucn} 3(n=5)$. Statistical analyses were performed using two-way ANOVA, followed by Scheffe's F post hoc test. Reproduction from [22] with permission of the publisher. Copyright 2003, Lippincott Wiliams \& Wilkins.
[40]. Long-term Ucn treatment not only has hypotensive effects but also may inhibit development of vascular remodeling in mesenteric arteries in spontaneously hypertensive rats [40]. Together, $\mathrm{CRF}_{2}$ receptor stimulation by $\mathrm{Ucn} 2$ may represent a novel approach to the treatment of arterial hypertension.

Endothelial Ucn1 has potent antioxidative properties. Treatment with pitavastatin ( $2 \mathrm{mg} /$ day) for 4 weeks increases the serum Ucn1 level from $11.0 \pm 6.5$ to $16.4 \pm 7.3 \mathrm{ng} / \mathrm{mL}$ in healthy subjects [7]. Thus, endothelial Ucn 1 may protect cardiomyocytes in inflammatory lesions. The selective blockade of CRF receptors expressed in human aortic endothelial cells also indicates that $C_{1} F_{1}$ receptor signaling mainly exerts anti-inflammatory actions [41]. The beneficial action of pitavastatin may be, in part, exerted via $\mathrm{CRF}_{1}$ receptor (Figure 1).

Ucn 1 and Ucn 2 have strong effects on IL- 6 gene expression and secretion in rat aortic smooth muscle A7r5 cells [23]. Cyclooxygenase-2 (COX-2) pathway is involved downstream in regulation of Ucn-increased IL-6 gene expression and IL-6 secretion (Figure 4) [23]. The increase that we observed in IL-6 levels following Ucn treatment of A7r5 cells suggests that smooth muscle cells may be a source of IL-6 secretion under physiological stress conditions. Increased IL6 protein levels would be expected to modify both humoral and cellular immunity [42]. In addition, IL-6 is able to stimulate ACTH and glucocorticoids secretion [43]. This combination of actions implies that increased IL-6 levels may have direct and indirect effects on the immune and other stress modulations. We have demonstrated previously that Ucn directly downregulates $\mathrm{CRF}_{2 \mathrm{~b}}$ receptor mRNA levels 


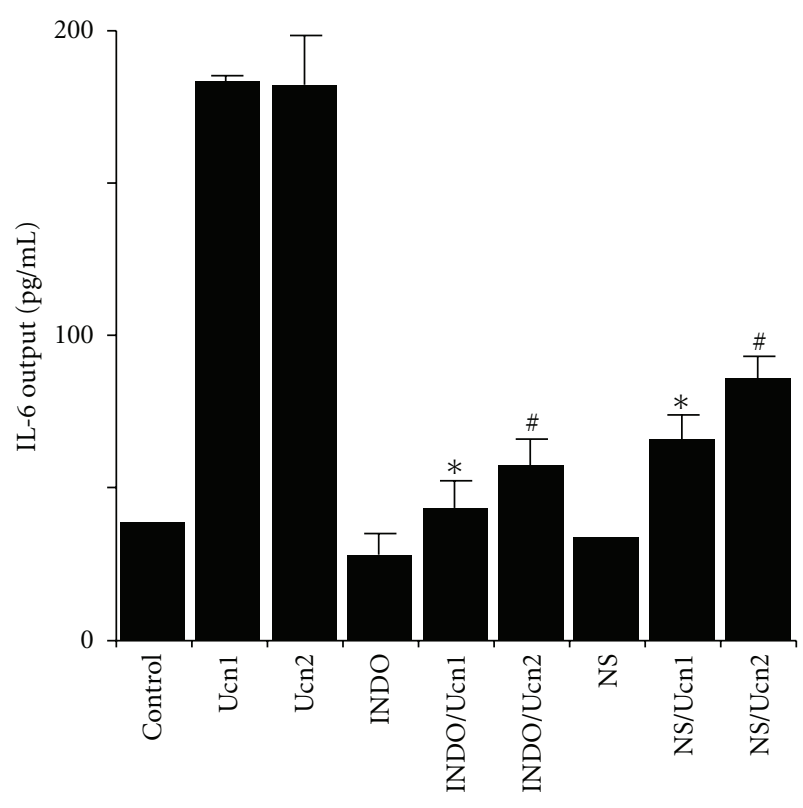

Figure 4: Effects of cyclooxygenase inhibitors on Ucn1- or Ucn2induced IL-6 output in A7r5 aortic smooth muscle cells. Cells were treated in triplicate, with the mean of three independent experiments (an average in triplicate was considered $n=1$; three experiments $n=3$ ) shown in figures. Statistical analyses were performed using one-way ANOVA, followed by Scheffe's F post hoc test. Cells were preincubated with medium containing indomethacin (INDO), NS-398 (NS), or vehicle for $30 \mathrm{~min}$ then incubated for $48 \mathrm{~h}$ with medium containing $100 \mathrm{nM} \mathrm{Ucn} 1, \mathrm{Ucn} 2$, or vehicle. ${ }^{*} P<0.0005$ (compared with only Ucn 1 ). ${ }^{\#} P<0.0005$ (compared with only Ucn2). Reproduction from [23] with permission of the publisher. Copyright 2006, The Endocrine Society.

[24]. Because cytokines such as IL-1 and IL-6 both decrease $\mathrm{CRF}_{2 \mathrm{~b}}$ receptor mRNA expression $[24,44]$, it is possible that Ucn and IL-6 contribute cooperatively to regulate the levels of $\mathrm{CRF}_{2 \mathrm{~b}}$ receptor mRNA in vascular cells. IL-6 may act as an autocrine and paracrine factor in the vessel wall.

Ucns have been suggested to have roles in regulation of blood pressure and in the pathophysiology of cardiovascular disease. Richards's group reports that plasma Ucn 1 in normal control subjects at 7.2 $\pm 2.9 \mathrm{pM}$ is significantly lower than levels recorded in the non-heart-failure symptomatic patients $(11.1 \pm 3.2 \mathrm{pM})$ [45]. Elevated plasma Ucn 1 in human heart failure reflects a beneficial compensatory response to this condition. Serum Ucn2 levels are elevated in mildto-moderate systolic dysfunction $(12.8 \pm 3.6$ versus $10.4 \pm$ $3.9 \mathrm{pg} / \mathrm{mL}$, resp.) [46]. The studies by Rademaker et al. suggest that Ucn 2 or Ucn 3 may have therapeutic potential in patients with heart failure $[47,48]$. Adjunct Ucn2 therapy with diuretics in heart failure is beneficial, because Ucn2 administration induces sustained improvements in hemodynamics and renal function, in association with inhibition of multiple vasoconstrictor/volume-retaining systems [49]. These findings support the therapeutic potential for Ucn2 in heart failure [50]. Ucn3 induces potent inhibition of sympathetic traffic directed toward the heart [51].
$\mathrm{Ucn} 1$ is a cardioprotective peptide and is also involved in cardiac hypertrophy. Ucn1-induced cardiomyocytes hypertrophy is associated with regulation of GSK-3 $\beta$, a pivotal kinase involved in cardiac hypertrophy, in a phosphatidylinositol-3-kinase- (PI3K-) dependent manner [52]. The expression of endogenous cardiac Ucns is increased by in vitro ischemia-reperfusion damage, and the addiction of exogenous Ucns is associated with reduction of myocardial cell death during ischemia-reperfusion damage [53]. Therefore, Ucns have a significant protection against myocardial ischaemia/reperfusion injury $[54,55]$.

\section{Conclusion}

HUVECs express Ucn1, Ucn2, and Ucn3 mRNAs and $\mathrm{CRF}_{2 \mathrm{a}}$ receptor mRNA. Differential regulation and roles of Ucns1-3 mRNA are suggested in HUVECs. Ucn 1 and 2 stimulate IL-6 gene transcription and secretion via $\mathrm{CRF}_{2}$ receptor activity in A7r5 aortic smooth muscle cells. Ucns are important and unique modulators of vascular smooth muscle cells and act directly or indirectly as autocrine and paracrine factors in the vascular system.

\section{Acknowledgment}

This work was supported in part by Health and Labour Science Research Grants (Research on Measures for Intractable Diseases) from the Ministry of Health, Labour, and Welfare of Japan.

\section{References}

[1] W. Vale, J. Spiess, C. Rivier, and J. Rivier, "Characterization of a 41-residue ovine hypothalamic peptide that stimulates secretion of corticotropin and $\beta$-endorphin," Science, vol. 213, no. 4514, pp. 1394-1397, 1981.

[2] J. Vauhan, C. Donaldson, J. Bittencourt et al., "Urocortin, a mammalian neuropeptide related to fish urotensin I and to cor-ti-cot-ro-pin-releasing factor," Nature, vol. 378, no. 6554, pp. 287-292, 1995.

[3] S. Y. Hsu and A. J. W. Hsueh, "Human stresscopin and stresscopin-related peptide are selective ligands for the type 2 corticotropin-releasing hormone receptor," Nature Medicine, vol. 7, no. 5, pp. 605-611, 2001.

[4] K. Lewis, C. Li, M. H. Perrin et al., "Identification of urocortin III, an additional member of the corticotropin-releasing factor (CRF) family with high affinity for the CRF2 receptor," Proceedings of the National Academy of Sciences of the United States of America, vol. 98, no. 13, pp. 7570-7575, 2001.

[5] T. M. Reyes, K. Lewis, M. H. Perrin et al., "Urocortin II: a member of the corticotropin-releasing factor (CRF) neuropeptide family that is selectively bound by type 2 CRF receptors," Proceedings of the National Academy of Sciences of the United States of America, vol. 98, no. 5, pp. 2843-2848, 2001.

[6] C. M. Bamberger, M. Wald, A. M. Bamberger, S. Ergün, F. U. Beil, and H. M. Schulte, "Human lymphocytes produce urocortin, but not corticotropin-releasing hormone," Journal of Clinical Endocrinology and Metabolism, vol. 83, no. 2, pp. 708711, 1998.

[7] T. Honjo, N. Inoue, R. Shiraki et al., "Endothelial urocortin has potent antioxidative properties and is upregulated by 
inflammatory cytokines and pitavastatin," Journal of Vascular Research, vol. 43, no. 2, pp. 131-138, 2006.

[8] K. Kageyama, M. J. Bradbury, L. Zhao, A. L. Blount, and W. W. Vale, "Urocortin messenger ribonucleic acid: tissue distribution in the rat and regulation in thymus by lipopolysaccharide and glucocorticoids," Endocrinology, vol. 140, no. 12, pp. 5651-5658, 1999.

[9] K. Takahashi, K. Totsune, O. Murakami et al., "Expression of urocortin III/stresscopin in human heart and kidney," Journal of Clinical Endocrinology and Metabolism, vol. 89, no. 4, pp. 1897-1903, 2004.

[10] W. Vale, J. Vaughan, and M. Perrin, "Corticotropin-releasing factor (CRF) family of ligands and their receptors," Endocrinologist, vol. 7, no. 1, pp. 3S-9S, 1997.

[11] C. P. Chang, R. I. Pearse, S. O’Connell, and M. G. Rosenfeld, "Identification of a seven transmembrane helix receptor for corticotropin- releasing factor and sauvagine in mammalian brain," Neuron, vol. 11, no. 6, pp. 1187-1195, 1993.

[12] R. Chen, K. A. Lewis, M. H. Perrin, and W. W. Vale, "Expression cloning of a human corticotropin-releasingfactor receptor," Proceedings of the National Academy of Sciences of the United States of America, vol. 90, no. 19, pp. 89678971, 1993.

[13] N. Vita, P. Laurent, S. Lefort et al., "Primary structure and functional expression of mouse pituitary and human brain corticotrophin releasing factor receptors," FEBS Letters, vol. 335, no. 1, pp. 1-5, 1993.

[14] T. W. Lovenberg, C. W. Liaw, D. E. Grigoriadis et al., "Cloning and characterization of a functionally distinct corticotropinreleasing factor receptor subtype from rat brain," Proceedings of the National Academy of Sciences of the United States of America, vol. 92, no. 3, pp. 836-840, 1995.

[15] M. Perrin, C. Donaldson, R. Chen et al., "Identification of a second corticotropin-releasing factor receptor gene and characterization of a cDNA expressed in heart," Proceedings of the National Academy of Sciences of the United States of America, vol. 92, no. 7, pp. 2969-2973, 1995.

[16] P. Stenzel, R. Kesterson, W. Yeung, R. D. Cone, M. B. Rittenberg, and M. P. Stenzel-Poore, "Identification of a novel murine receptor for corticotropin-releasing hormone expressed in the heart," Molecular Endocrinology, vol. 9, no. 5, pp. 637-645, 1995.

[17] T. Kishimoto, R. V. Pearse II, C. R. Lin, and M. G. Rosenfeld, "A sauvagine/corticotropin-releasing factor receptor expressed in heart and skeletal muscle," Proceedings of the National Academy of Sciences of the United States of America, vol. 92, no. 4, pp. 1108-1112, 1995.

[18] T. Suda, K. Kageyama, S. Sakihara, and T. Nigawara, "Physiological roles of urocortins, human homologues of fish urotensin I, and their receptors," Peptides, vol. 25, no. 10, pp. 1689-1701, 2004.

[19] K. Kageyama, C. Li, and W. W. Vale, "Corticotropin-releasing factor receptor type 2 messenger ribonucleic acid in rat pituitary: localization and regulation by immune challenge, restraint stress, and glucocorticoids," Endocrinology, vol. 144, no. 4, pp. 1524-1532, 2003.

[20] T. W. Lovenberg, D. T. Chalmers, C. Liu, and E. B. De Souza, " $\operatorname{CRF}(2 \alpha)$ and $\operatorname{CRF}(2 \beta)$ receptor mRNAs are differentially distributed between the rat central nervous system and peripheral tissues," Endocrinology, vol. 136, no. 9, pp. 41394142, 1995.

[21] K. Kageyama, K. Hanada, and T. Suda, “Differential regulation of urocortins 1-3 mRNA in human umbilical vein endothelial cells," Regulatory Peptides, vol. 155, no. 1-3, pp. 131-138, 2009.
[22] K. Kageyama, K. I. Furukawa, I. Miki, K. Terui, S. Motomura, and T. Suda, "Vasodilative effects of urocortin II via protein kinase A and a mitogen-activated protein kinase in rat thoracic aorta," Journal of Cardiovascular Pharmacology, vol. 42, no. 4, pp. 561-565, 2003.

[23] K. Kageyama, K. Hanada, T. Nigawara et al., "Urocortin induces interleukin-6 gene expression via cyclooxygenase-2 activity in aortic smooth muscle cells," Endocrinology, vol. 147, no. 9, pp. 4454-4462, 2006.

[24] K. Kageyama, G. E. Gaudriault, M. J. Bradbury, and W. W. Vale, "Regulation of corticotropin-releasing factor receptor type $2 \beta$ messenger ribonucleic acid in the rat cardiovascular system by urocortin, glucocorticoids, and cytokines," Endocrinology, vol. 141, no. 7, pp. 2285-2293, 2000.

[25] K. Kageyama, G. E. Gaudriault, T. Suda, and W. W. Vale, "Regulation of corticotropin-releasing factor receptor type $2 \beta$ mRNA via cyclic AMP pathway in A7r5 aortic smooth muscle cells," Cellular Signalling, vol. 15, no. 1, pp. 17-25, 2003.

[26] T. Audhya, R. Jain, and C. S. Hollander, "Receptor-mediated immunomodulation by corticotropin-releasing factor," Cellular Immunology, vol. 134, no. 1, pp. 77-84, 1991.

[27] K. Kageyama, H. Watanobe, and K. Takebe, "In vivo evidence that arginine vasopressin is involved in the adrenocorticotropin response induced by interleukin- 6 but not by tumor necrosis factor- $\alpha$ in the rat," NeuroImmunoModulation, vol. 2, no. 3, pp. 137-140, 1995.

[28] K. Karalis, L. J. Muglia, D. Bae, H. Hilderbrand, and J. A. Majzoub, "CRH and the immune system," Journal of Neuroimmunology, vol. 72, no. 2, pp. 131-136, 1997.

[29] M. Kainoh, I. Maruyama, S. Nishio, and T. Nakadate, "Enhancement by beraprost sodium, a stable analogue of prostacyclin, in thrombomodulin expression on membrane surface of cultured vascular endothelial cells via increase in cyclic AMP level," Biochemical Pharmacology, vol. 41, no. 8, pp. 1135-1140, 1991.

[30] S. Q. Xu, K. Mahadev, X. Wu et al., "Adiponectin protects against angiotensin II or tumor necrosis factor $\alpha$-induc-ed endothelial cell monolayer hyperpermeability: role of cAMP/ PKA signaling," Arteriosclerosis, Thrombosis, and Vascular Biology, vol. 28, no. 5, pp. 899-905, 2008.

[31] Y. Seya, T. Fukuda, K. Isobe, Y. Kawakami, and K. Takekoshi, "Effect of norepinephrine on RhoA, MAP kinase, proliferation and VEGF expression in human umbilical vein endothelial cells," European Journal of Pharmacology, vol. 553, no. 1-3, pp. 54-60, 2006.

[32] L. Zhao, C. J. Donaldson, G. W. Smith, and W. W. Vale, “The structures of the mouse and human urocortin genes (Ucn and UCN)," Genomics, vol. 50, no. 1, pp. 23-33, 1998.

[33] L. Lubomirov, H. Gagov, P. Petkova-Kirova, D. Duridanova, V. U. Kalentchuk, and R. Schubert, "Urocortin relaxes rat tail arteries by a PKA-mediated reduction of the sensitivity of the contractile apparatus for calcium," British Journal of Pharmacology, vol. 134, no. 7, pp. 1564-1570, 2001.

[34] L. Schilling, C. Kanzler, P. Schmiedek, and H. Ehrenreich, "Characterization of the relaxant action of urocortin, a new peptide related to corticotropin-releasing factor in the rat isolated basilar artery," British Journal of Pharmacology, vol. 125, no. 6, pp. 1164-1171, 1998.

[35] K. Terui, A. Higashiyama, N. Horiba, K. I. Furukawa, S. Motomura, and T. Suda, "Coronary vasodilation and positive inotropism by urocortin in the isolated rat heart," Journal of Endocrinology, vol. 169, no. 1, pp. 177-183, 2001.

[36] S. Wang, X. Zhu, B. Cong et al., "Estrogenic action on arterial smooth muscle: permissive for maintenance of CRHR2 
expression," Endocrinology, vol. 153, no. 4, pp. 1915-1924, 2012.

[37] E. Grossini, C. Molinari, D. A. S. G. Mary et al., "Urocortin II induces nitric oxide production through cAMP and $\mathrm{Ca} 2+$ related pathways in endothelial cells," Cellular Physiology and Biochemistry, vol. 23, no. 1-3, pp. 87-96, 2009.

[38] K. Kageyama, S. Sakihara, M. Yamashita et al., "A case of multiple endocrine neoplasia type II accompanied by thyroid medullary carcinoma and pheochromocytomas expressing corticotropin-releasing factor and urocortins," American Journal of the Medical Sciences, vol. 335, no. 5, pp. 398-402, 2008.

[39] T. Dieterle, S. Meili-Butz, K. Bühler et al., "Immediate and sustained blood pressure lowering by urocortin 2 a novel approach to antihypertensive therapy?" Hypertension, vol. 53, no. 4, pp. 739-744, 2009.

[40] J. Chen, J. Tao, R. Zhang, Y. Xu, T. Soong, and S. Li, “Urocortin inhibits mesenteric arterial remodeling in spontaneously hypertensive rats," Peptides, vol. 30, no. 6, pp. 1117-1123, 2009.

[41] Y. Inada, K. Ikeda, K. Tojo, M. Sakamoto, Y. Takada, and N. Tajima, "Possible involvement of corticotropin-releasing factor receptor signaling on vascular inflammation," Peptides, vol. 30, no. 2, pp. 365-372, 2009.

[42] P. Lydyard and C. Grossi, "The lymphoid system," in Immunology, I. Roitt, J. Brostoff, and D. Male, Eds., pp. 31-41, Mosby, London, UK, 5th edition, 1998.

[43] M. Venihaki, P. Dikkes, A. Carrigan, and K. P. Karalis, "Corticotropin-releasing hormone regulates IL-6 expression during inflammation," Journal of Clinical Investigation, vol. 108, no. 8, pp. 1159-1166, 2001.

[44] K. Kageyama and T. Suda, "Regulation of corticotropinreleasing factor receptor type $2 \beta$ messenger ribonucleic acid by interleukin- $1 \beta$ in rat vascular smooth muscle cells," NeuroImmunoModulation, vol. 9, no. 6, pp. 326-332, 2001.

[45] S. P. Wright, R. N. Doughty, C. M. Frampton, G. D. Gamble, T. G. Yandle, and A. M. Richards, "Plasma urocortin 1 in human heart failure," Circulation, vol. 2, no. 5, pp. 465-471, 2009.

[46] E. Topal, J. Yağmur, B. Otlu et al., "Relationship of urocortin2 with systolic and diastolic functions and coronary artery disease: an observational study," Anadolu Kardiyoloji Dergisi, vol. 12, no. 2, pp. 115-120, 2012.

[47] M. T. Rademaker, V. A. Cameron, C. J. Charles, and A. M. Richards, "Integrated hemodynamic, hormonal, and renal actions of urocortin 2 in normal and paced sheep: beneficial effects in heart failure," Circulation, vol. 112, no. 23, pp. 36243632, 2005.

[48] M. T. Rademaker, V. A. Cameron, C. J. Charles, and A. M. Richards, "Urocortin 3: haemodynamic, hormonal, and renal effects in experimental heart failure," European Heart Journal, vol. 27, no. 17, pp. 2088-2098, 2006.

[49] M. T. Rademaker, C. J. Charles, M. G. Nicholls, and A. M. Richards, "Urocortin 2 inhibits furosemide-induced activation of renin and enhances renal function and diuretic responsiveness in experimental heart failure," Circulation, vol. 2, no. 6, pp. 532-540, 2009.

[50] M. T. Rademaker, C. J. Charles, L. J. Ellmers, L. K. Lewis, M. G. Nicholls, and A. M. Richards, "Prolonged urocortin 2 administration in experimental heart failure: sustained hemodynamic, endocrine, and renal effects," Hypertension, vol. 57, no. 6, pp. 1136-1144, 2011.

[51] C. J. Charles, D. L. Jardine, M. T. Rademaker, and M. Richards, "Urocortin 3 inhibits cardiac sympathetic nerve activity in conscious sheep," Journal of Cardiovascular Pharmacology, vol. 58, no. 4, pp. 418-423, 2011.
[52] D. Gruson, A. Ginion, N. Decroly et al., "Urocortin-induced cardiomyocytes hypertrophy is associated with regulation of the GSK-3 $\beta$ pathway," Heart and Vessels, pp. 1-6, 2011.

[53] R. Raddino, C. Pedrinazzi, G. Zanini et al., "Urocortin: molecular biology and cardiovascular effects," Giornale Italiano di Cardiologia, vol. 8, no. 4, pp. 236-245, 2007.

[54] S. P. Barry, K. M. Lawrence, J. McCormick et al., "New targets of urocortin-mediated cardioprotection," Journal of Molecular Endocrinology, vol. 45, no. 2, pp. 69-85, 2010.

[55] T. I. Emeto, J. V. Moxon, C. Rush, L. Woodward, and J. Golledge, "Relevance of urocortins to cardiovascular disease," Journal of Molecular and Cellular Cardiology, vol. 51, no. 3, pp. 299-307, 2011. 


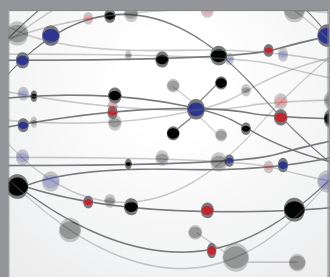

The Scientific World Journal
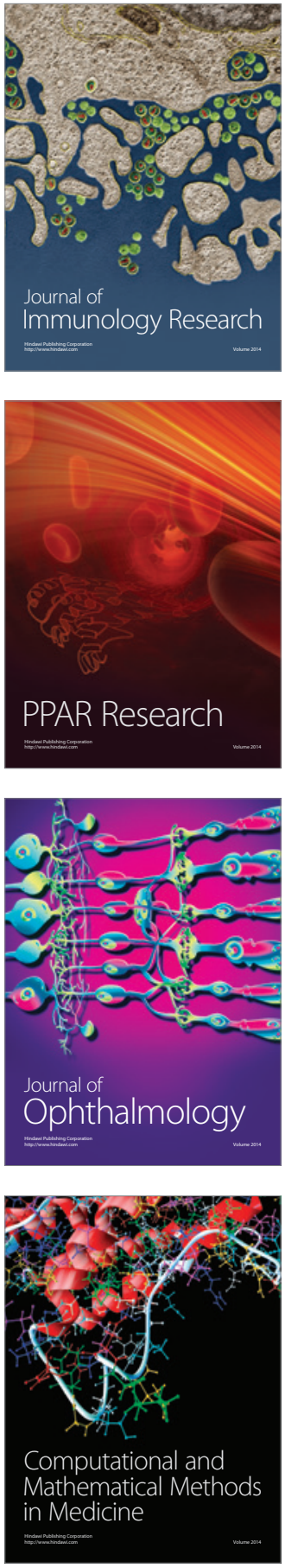

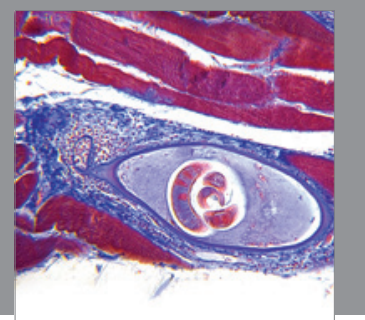

Gastroenterology

Research and Practice
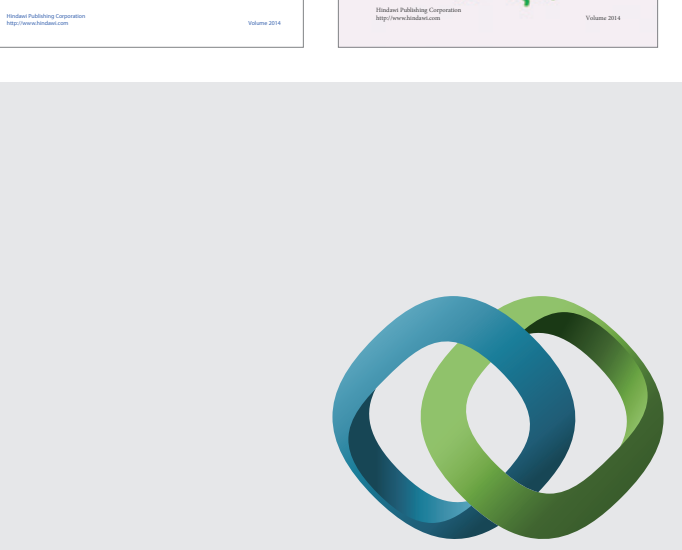

\section{Hindawi}

Submit your manuscripts at

http://www.hindawi.com
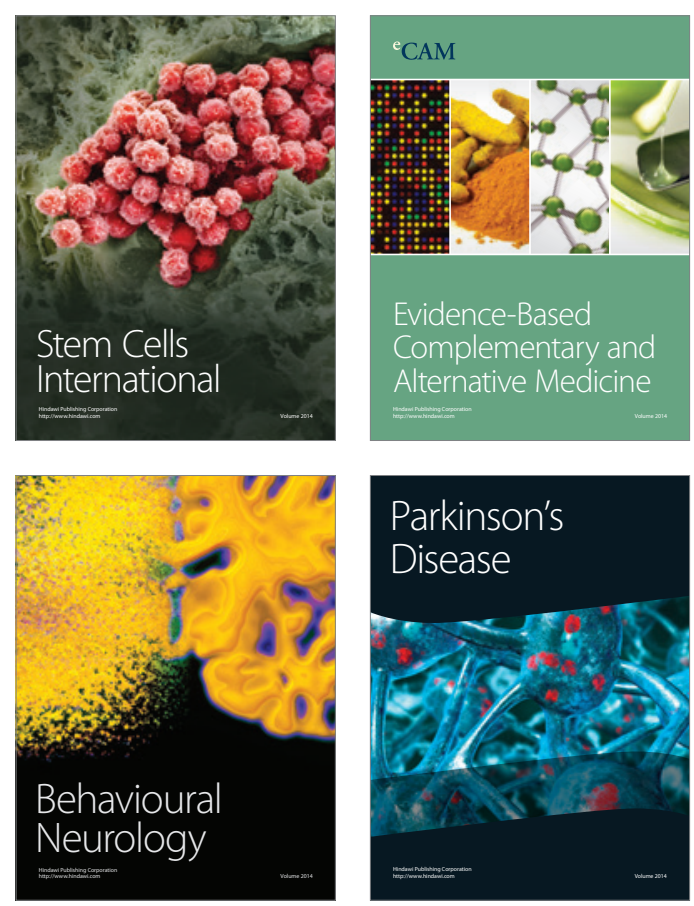

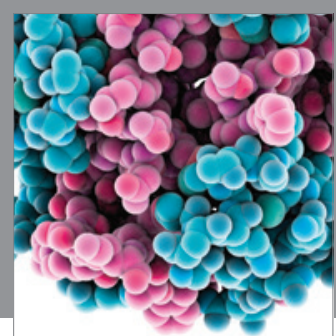

Journal of
Diabetes Research

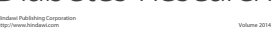

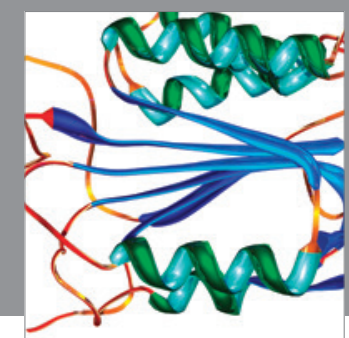

Disease Markers
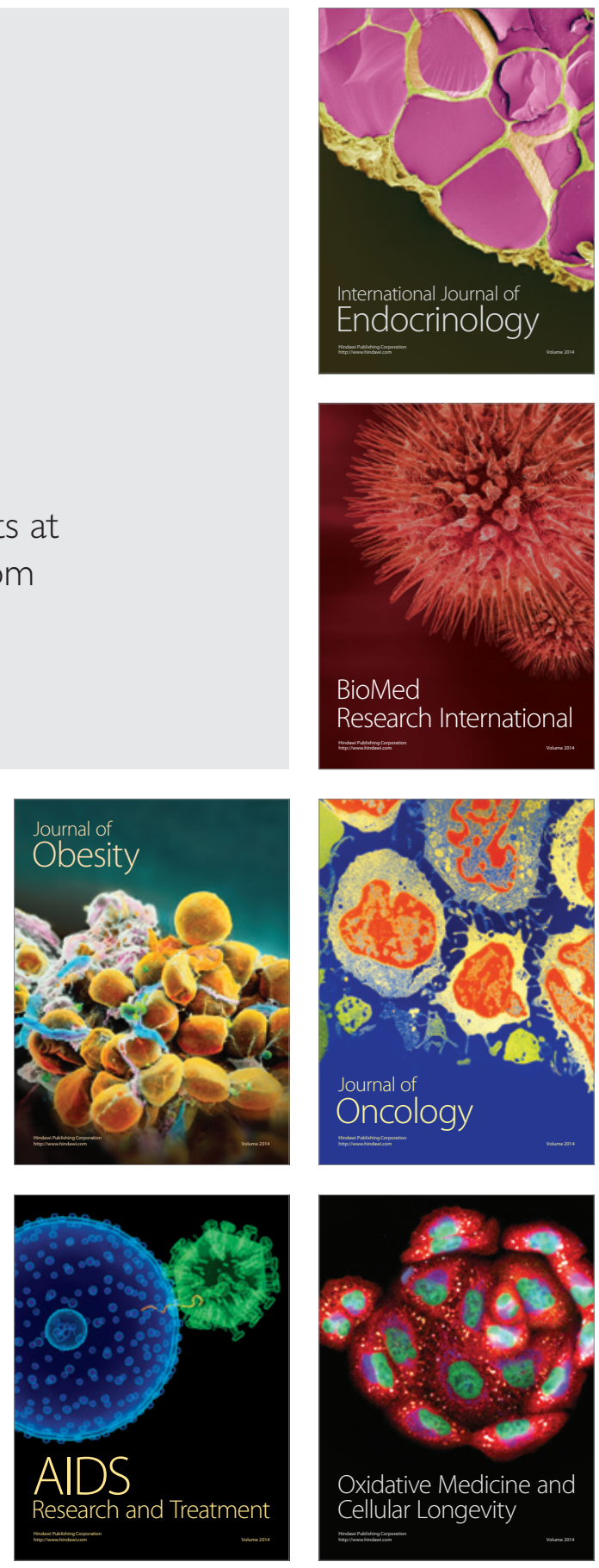